\title{
REMOTE SENSING OF VEGETATION RECOVERY IN GRASSLANDS AFTER THE 1988 FIRES IN Yellowstone NATiOnAL PARK
}

\author{
EVELYN MERRILL • DEPARTMENT OF ZOOLOGY AND PHYSIOLOGY \\ RONALD MARRS $\bullet$ DEPARTMENT OF GEOLOGY \\ UNIVERSITY OF WYOMING $\bullet$ LARAMIE
}

\section{$\checkmark \quad$ INTRODUCTION}

Traditional methods for measurement of vegetative characteristics can be time-consuming and labor-intensive, especially across large areas. Yet such estimates are necessary to investigate the effects of large scale disturbances on ecosystem components and processes. Because foliage of plants differentially absorbs and reflects energy within the electromagnetic spectrum, one alternative for monitoring vegetation is to use remotely sensed spectral data (Tueller 1989). Spectral indices developed from field radiometric and Landsat data have been used successfully to quantify green leaf area, biomass, and total yields in relatively homogeneous fields for agronomic uses (Shibayama and Akiyama 1989), but have met with variable success in wildland situations (Pearson et al. 1976). Interference from soils (Hardinsky et al. 1984, Huete et al. 1985), weathered litter (Huete and Jackson 1987), and senesced vegetation (Sellers 1985) have diminished the relationship between green vegetation characteristics and various vegetation indices.

In 1987, we found that a linear combination of Landsat Multi-spectral Scanner (MSS) band 7 and the ratio of MSS bands 6 to 4 explained $63 \%$ of the variation in green herbaceous phytomass (GHP) in sagebrush-grasslands on ungulate summer range in the northeastern portion of Yellowstone National Park (Merrill et al. 1993). The extensive fires that occurred in the Park in the summer of 1988 provided an opportunity to determine whether remote sensing could be used to estimate green phytomass in burned areas and to monitor grassland vegetation recovery in the Park after the fires. Remote sensing has previously been used to follow succession of seral stages in pine forests (Jakubauskas et al. 1990) after burning and to monitor plant cover in tundra (Hall et al. 1980) after wildfires.

The objectives of our study were to (1) develop a model for predicting GHP in sagebrushgrassland communities using 1989 and 1990 Landsat TM spectral information and field data on GHP, (2) validate the model by comparing predictions made from it to actual field data collected in 1991, and if successful, (3) compare initial vegetation recovery in burned areas relative to unburned sagebrushgrassland. We chose to use thematic mapper (TM) data rather than MSS data to increase the band options for developing a predictive model.

\section{- STUdY AREA}

The study was conducted in the northeast portion of Yellowstone National Park with major focus on the upper Lamar, Cache and Calfee River drainages and the Mirror Plateau. General descriptions of physiogamy and soils are given by Despain (1990). Elevations range from 1,500 to $3,300 \mathrm{~m}$. Climate of the Park is characterized by long, cold winters and short dry summers, but 
climatic patterns within the Park vary considerably (Farnes 1975 in Houston 1982). Mean annual precipitation in Cooke City, located to the northeast of the Park is $67.0 \mathrm{~cm}$ (26.8 in) and mean daily temperature in January and July is $-10.3^{\circ} \mathrm{C}\left(13.5^{\circ} \mathrm{F}\right)$ and $13.9^{\circ} \mathrm{C}\left(57.1^{\circ} \mathrm{F}\right)$, respectively.

Descriptions of vegetation communities in the park have been given by Despain (1990). Our work focused on the non-forested plant communities within the study area. These included sagebrush Artemisia tridentata communities which have an understory of bluebunch wheatgrass Agropyron spicatum in dry areas, and Idaho fescue Festuca idahoensis on the more mesic sites. Silver sagebrush Artemisia cana with an Idaho fescue co-dominant is found on areas associated with high water table such as stream banks and seeps. High elevation grasslands are dominated by Idaho fescue/tufted hairgrass Deschampsia cespitosa and tufted hairgrass/sedge Carex spp. At intermediate elevations, Idaho fescue/wheatgrass Agropyron spicatum and $A$. caninum communities are encountered with the latter dominating in the more mesic sites.

Elk Cervus elaphus, mule deer Odocoileus hemionus, bison Bison bison, moose Alces alces, bighorn sheep Ovis canadensis, and pronghorn Antilocapra americana are the major ungulates in this area (Houston 1982).

\section{$\checkmark \quad$ METHODS}

\section{VEGETATION SAMPLING}

Vegetation data were collected in the field from July 25 to August 10 in 1989, July 30 to August 11 in 1990, and July 30 to August 11 in 1991 across two ungulate summer ranges (Norris-Cache/Calfee ridge complex and Mirror Plateau). Each site encompassed at least 0.81 hectares ( 9 TM pixels) of relatively homogeneous vegetation. At each site, elevation, aspect (degrees), and average slope (\%) of the plot were recorded using 1:24,000 topographic maps and the site mapped. Grassland habitat types followed Yellowstone National Park habitat mapping (Despain 1990).

We qualitatively assessed the intensity of burning in the field at each site according to the following categories: (1) very hot: $\geq 80 \%$ of the ground cover and litter consumed; presence of shrubs noted only by trunk stubs; usually heavy ash layer, (2) moderate burn: $<80 \%$ but usually $>35 \%$ of the ground cover and litter consumed; few live shrubs but standing dead shrubs present, (3) light burn: < $35 \%$ ground cover and litter consumed; many live shrubs remaining, (4) no burn.

A double sampling approach was used to estimate biomass of green forbs, green grasses, and standing dead herbaceous vegetation at each site (Eberhardt and Simmons 1987). Percent cover of graminoids, forbs, bareground, rock, moss, lichens, and wood were visually estimated and average heights of plant types (forbs, graminoids, standing herbaceous phytomass) were measured in 30 microplots $\left(0.01 \mathrm{~m}^{2}\right)$. An index of plant volume was calculated (canopy cover $x$ plant height) for each of the 30 microplots. Ten of the microplots at each site were clipped to ground level. Vegetation was separated into green graminoids, green forbs, and standing dead herbaceous material. A criterion of $\geq$ $25 \%$ "green" was used to differentiate green from senescent (standing dead) plants. Biomass samples were dried at $70^{\circ} \mathrm{C}$ for 48 hours and weighed to the nearest $0.1 \mathrm{gm}$. The ratio of dry plant biomass to plant volume in clipped microplots at a site was used to estimate dry plant biomass in the 20 microplots which were not clipped.

Differences in mean standing dead, green forb, green graminoid, and total (green plus standing dead) biomass at sites that were sampled in all 3 years were tested using a Wilcoxon matched-pairs signed-ranks test. Differences in plant biomass between 3 burn categories (unburned, lightly burned, moderately to severely burned) were tested within years using Kruskal-Wallis one-way analysis of variance, and between two burn categories (unburned to lightly burned, moderately to severely burned) using a Mann-Whitney $U$ test.

\section{LANDSAT DATA ACQUISITION AND PREPROCESSING}

We used TM data from Landsat satellite 5 to quantify spectral characteristics of our study area. TM imagery for 2 August 1989, 13 August 1990, 31 July 1990 of the study area were acquired from EOSAT by the National Park Service. Due to mechanical problems with the receiving station in 
Golden California, EOSAT was unable to provide us with data from our projected 6 August 1990 satellite overpass. The closest date to our field sampling (July 30 - August 11) for which imagery was available was 13 August 1990. Data from this overpass was less than ideal because the date of the overpass was outside our sampling window and there were considerable clouds in the scene. As a result, we were unable to obtain spectral values for 6 field plots sampled in 1990.

Digital data were transferred from 9-track computer tape to the Micro-computer Image Processing System (MIPS) for data processing. Data from each scene were georeferenced to $1: 24,000$ USGS topographic using 8 control points. Environmental conditions that differed among years at the time of the satellites overpasses, such as sun angle and atmospheric conditions, were standardized to 1989 conditions in the following manner. First, we located 6 control sites of 9 TM pixels each in the 3 images, including bright landscape elements (Wahb hot springs and Lamar trail thermal area) and dark landscape elements (Trout and Soda Butte Lakes; rock faces of Abiathar and Thunderer peaks). Second, we recorded the spectral values of the 9 pixels for each spectral band at each site and calculated the average for the site. Third, we estimated the parameters of a linear relationship between average spectral values of each band in 1989 to the other 2 years (Appendix I). Finally, we used the relationships derived from the control points for each band to adjust reflectance values of all pixels in 1990 and 1991 to 1989.

\section{RELATIÓNSHIP BETWEEN GREEN PHYTOMASS AND SPECTRAL VALUES}

Values for each of the 6 TM bands were recorded for 9 pixels $(0.81 \mathrm{ha})$ encompassing each field site and averaged to represent the spectral value of the site. Linear combinations of the TM values, as well as published vegetation indices (Jackson 1983), were related to field estimates of biomass at field sites using least squares linear regression. Three indices were based on ratios of the red and near infrared (NIR) TM bands: the ratio vegetation index $(\mathrm{RVI}=\mathrm{NIR} / \mathrm{red})$, the normalized difference index $(\mathrm{NDVI}=(\mathrm{NIR}-\mathrm{red}) /(\mathrm{NIR}+\mathrm{red})$ and the transformed vegetation index (TVI $=$ SQRT(ND + 0.05) (Huete and Jackson 1987). The soil brightness index (SBI), the perpendicular vegetation index
(PVI), and the green vegetation index (GVI) were derived using the Graham-Schmidt orthogonalization process (Jackson 1983) in the MIPS software. Jackson (1983) showed that these indices minimize soil background variations while improving green vegetation signals.

We evaluated the relationship between the Landsat spectral values and the field estimates of biomass in two steps. First, the regressions between vegetative and spectral characteristics were evaluated based on their $\mathrm{F}$ value $(\underline{\mathrm{P}} \leq 0.05)$, the amount of variation in the dependant variable explained by the independent variables $\left(r^{2}\right)$, and the standard error of the estimate. Second, 21 field sites were sampled in more than one year. We used data from only one year to develop relationships between spectral characteristics and green herbaceous biomass. The remaining data were used to "validate" estimates of phytomass predicted from spectral values and actual field data.

\section{- RESULTS}

\section{FIELD ESTIMATES OF PHYTOMASS}

Vegetation was sampled at 62 individual field sites, with 21 sites resampled in all 3 years (Table 1). Plots were distributed about equally among Lamar Flat-Norris Mount, Cache-Calfee Ridge, and the Mirror Plateau. Graminoids consistently averaged about $50 \%$ of the total green herbaceous phytomass (GHP) in the 3 years of the study (Table 2). Biomass of green forbs, green graminoids, and total herbaceous biomass (green biomass plus standing dead) on the 21 sites sampled each year was higher in 1990 than in 1989 and 1991 $(\underline{\mathrm{P}}<0.05)$. The proportion of total herbaceous vegetation that was standing dead was lower in 1989 $(0.04 \pm 0.06, x \pm$ s.d. $)$ than in $1990(0.12 \pm 0.11)$ and lower in 1990 than in $1991(0.24 \pm 0.17)(\underline{P} \leq$ $0.01)$.

There were no significant differences in biomass of green graminoids and forbs between unburned, lightly burned, and moderately to severely burned in any year, but sample sizes within each burn category were low ( $5-8$ sites). When sites were combined into severely to moderately burned $(n=8)$ and lightly to unburned $(n=13)$, graminoid biomass was lower but not significantly lower on severely to 
Table 1. Location and characteristics of field sites sampled during August of 1989,1990 and Yellowstone National Park.

\begin{tabular}{|c|c|c|c|c|c|c|c|c|c|c|c|c|c|c|c|}
\hline \multirow{3}{*}{$\begin{array}{c}\begin{array}{c}\text { Plot } \\
\#\end{array} \\
101 \\
102\end{array}$} & \multirow{2}{*}{$\begin{array}{l}\text { Year } \\
1989,\end{array}$} & \multicolumn{2}{|c|}{ Sampled } & \multicolumn{6}{|c|}{ Latitude/Longitude } & Location & \multirow{2}{*}{$\begin{array}{c}\text { Burn' } \\
\text { T3 }\end{array}$} & \multirow{2}{*}{$\begin{array}{c}\begin{array}{c}\text { Elev } \\
\text { (m) }\end{array} \\
7520\end{array}$} & \multirow{2}{*}{$\begin{array}{c}\begin{array}{c}\text { Asp } \\
\left({ }^{\circ}\right)\end{array} \\
180\end{array}$} & \multirow{2}{*}{$\begin{array}{r}\begin{array}{l}\text { Slp } \\
\left({ }^{\circ}\right)\end{array} \\
15\end{array}$} & \multirow{3}{*}{$\begin{array}{c}\text { Habitat } \\
\text { Type }\end{array}$} \\
\hline & & & 1991 & 44 & 50 & 38.6 & 110 & 08 & 32.7 & Lower Norris & & & & & \\
\hline & & 1990, & 1991 & 44 & 50 & 51.7 & 110 & 09 & 03.5 & Lower Norris & No & 7740 & 179 & 17 & \\
\hline 103 & 1989, & 1990 & 1991 & 44 & 50 & 28.3 & 110 & 07 & 49.7 & Middle Norris & T1 & 7800 & 252 & 15 & TFG \\
\hline 104 & 1989, & 1990, & 1991 & 44 & 50 & 13.6 & 110 & 08 & 07.1 & Middle Norris & T2 & 7520 & 302 & 9 & TFG \\
\hline 105 & 1989, & 1990 & 1991 & 44 & 49 & 16.0 & 110 & 08 & 35.0 & Lower Cache & T2 & 7460 & 250 & 14 & TFG \\
\hline 106 & 1989, & 1990, & 1991 & 44 & 49 & 20.2 & 110 & 08 & 25.2 & Lower Cache & No & 7700 & 253 & 6 & FN \\
\hline 107 & 1989, & $1990^{\circ}$ & & 44 & 48 & 21.0 & 110 & 05 & 49.2 & Upper Cache & No & 8140 & 0 & 0 & FN \\
\hline 108 & $1989^{\circ}$ & & & 44 & 48 & 11.1 & 110 & 06 & 40.0 & Upper Cache & No & 7940 & 230 & 1 & TFG \\
\hline 109 & 1989, & 1990. & 1991 & 44 & 48 & 47.3 & 110 & 05 & 58.6 & Upper Cache & T3 & 8025 & 2 & 3 & TFG \\
\hline 110 & 1989, & 1990, & 1991 & 44 & 48 & 19.1 & 110 & 06 & 24.4 & Upper Cache & No & 7960 & 200 & 18 & TFG \\
\hline 111 & 1989, & 1990 & 1991 & 44 & 48 & 06.9 & 110 & 06 & 40.0 & Upper Cache & No & 7850 & 0 & 0 & TFG \\
\hline 112 & $1989^{\circ}$ & & & 44 & 48 & 18.2 & 110 & 07 & 19.2 & Upper Cache & No & 7760 & 295 & 4 & TFG \\
\hline 113 & 1989, & 1990, & 1991 & 44. & .48 & 45.9 & 110 & 07 & 40.9 & Upper Cache & T3 & 7680 & 211 & 11 & TFG \\
\hline 114 & 1989, & 1990, & 1991 & 44 & 51 & 05.0 & 110 & 11 & 03.1 & Lamar Flat & $\mathrm{T} 2$ & 6640 & 0 & 0 & TF \\
\hline 115 & 1989, & 1990, & 1991 & 44 & 50 & 59.7 & 110 & 11 & 12.3 & Lamar Flat & No & 6640 & 0 & 0 & TFG \\
\hline 116 & $1989^{\circ}$ & & & 44 & 51 & 05.0 & 110 & 11 & 03.1 & Upper Lamar Flat & T2 & 6710 & 0 & 1 & TF \\
\hline 121 & 1989, & 1990, & 1991 & 44 & 48 & 30.3 & 110 & 11 & 59.7 & Opal Creek & $\mathrm{T} 2$ & 8800 & 127 & 8 & FNG \\
\hline 122 & 1989 , & 1990, & 1991 & 44 & 48 & 44.3 & 110 & 11 & 51.5 & Opal Creek & T2 & 8740 & 95 & 15 & FNG \\
\hline 123 & 1989, & 1990 & & 44 & 48 & 26.1 & 110 & 11 & 53.5 & Opal Creek & T3 & 8760 & 101 & 6 & FNG \\
\hline 124 & 1989, & 1990, & 1991 & 44 & 47 & 56.8 & 110 & 11 & 00.3 & Above Opal Camp & No & 8960 & 90 & 6 & FNG \\
\hline 125 & 1989, & 1990, & 1991 & 44 & 47 & 28.0 & 110 & 11 & 22.0 & Above Opal Camp & No & 8800 & 170 & 15 & FNG \\
\hline 126 & 1989, & 1990, & 1991 & 44 & 47 & 16.1 & 110 & 10 & 55.4 & Above Opal Camp & T3 & 8760 & 353 & 4 & FNG \\
\hline 127 & 1989, & 1990, & 1991 & 44 & 48 & 10.6 & 110 & 12 & 13.6 & Opal Creek & T3 & 8800 & 15 & 1 & FNG \\
\hline 128 & 1989, & 1990, & 1991 & 44 & 48 & 26.7 & 110 & 11 & 44.5 & Opal Creek & No & 8680 & 287 & 8 & FNG \\
\hline 129 & 1989, & $1990^{\circ}$ & & 44 & 50 & 12.7 & 110 & 12 & 10.2 & Specimen Ridge & T2 & 75 & 80 & 7 & TFG \\
\hline 130 & $1989^{\circ}$ & & & 44 & 48 & 25.3 & 110 & 13 & 35.8 & Mirror Plateau & No & 9120 & 192 & 20 & FNG \\
\hline 131 & 1989 & & & 44 & 48 & 51.5 & 110 & 14 & 11.8 & Mirror Plateau & No & 9170 & 0 & 2 & FNG \\
\hline 132 & 1989 & & & 44 & 49 & 09.8 & 110 & 13 & 45.2 & Top Specimen Ridge $\mathrm{Tr}$ & No & 8840 & 150 & 20 & FNG \\
\hline 133 & 1989, & 1990, & 1991 & 44 & 50 & 27.7 & 110 & 09 & 46.2 & Above Norris Hot Sp & T2 & 7000 & 239 & 7 & TFG \\
\hline 134 & 1989, & 199 & 1991 & 44 & 50 & 18.9 & 110 & 09 & 19.5 & Lower Norris & T1 & 7250 & 213 & 14 & TFG \\
\hline 136 & $1989^{\circ}$ & & & 44 & 50 & 57.8 & 110 & 09 & 51.4 & West of Norris Cliff & T2 & 7440 & 180 & 15 & FA \\
\hline 137 & 1989 & & & 44 & 51 & 05.8 & 110 & 06 & 48.6 & Upper Norris & No & 8130 & 121 & 5 & TFG \\
\hline 138 & 1989, & & 1991 & 44 & 51 & 07.2 & 110 & 08 & 03.5 & Pk Midway To Nor & $\mathrm{N}$ & 8250 & 171 & 10 & FNG \\
\hline 139 & 1989, & 1990, & 1991 & 44 & 50 & 54.2 & 110 & 09 & 06.2 & Top/Draw Mid-NoI & $\mathrm{N}$ & 78 & 276 & 6 & \\
\hline 140 & 1989, & $1990^{\circ}$ & & 44 & 50 & 57.8 & 110 & 09 & 30.7 & Norris/Next To Cliff & No & 7800 & 294 & 7 & TFG \\
\hline 141 & & 1990, & 1991 & 44 & 50 & 54.3 & 110 & 09 & 57.0 & Lower Norris & T2 & 7440 & 220 & 18 & FA \\
\hline 142 & & 1990, & 1991 & 44 & 50 & 50.2 & 110 & 06 & 55.8 & Upper Norris & No & 8000 & 187 & 14 & TFG \\
\hline 143 & & 1990, & 1991 & 44 & 50 & 46.6 & 110 & 07 & 56.7 & Midway to Norris & $\mathrm{N}$ & 7700 & 186 & 14 & FNG \\
\hline 144 & & 1990, & 1991 & 44 & 50 & 33.6 & 110 & 10 & 15.0 & Lower Norris & T3 & 6760 & 261 & 6 & FNG \\
\hline 145 & & $1990^{\circ}$ & & 44 & 48. & 46.1 & 110 & 06 & 57.0 & Upper Cache & No & 8140 & 211 & 7 & FNG \\
\hline 146 & & 1990 & & 44 & 48 & 41.6 & 110 & 06 & 48.0 & Upper Cache & $\mathrm{N}$ & 8030 & 148 & 12 & FNG \\
\hline 147 & & 1990 & & 44 & 48 & 35.7 & 110 & 07 & 20.3 & Upper Cache & $\mathbf{N}$ & 77 & 296 & 1 & D \\
\hline 148 & & 1990 & & 44 & 48 & 56.1 & 110 & 07 & 37.3 & Upper Cache & & 78 & 55 & 2 & FN \\
\hline 149 & & 1990 & & 44 & 48 & 38.3 & 110 & 06 & 57.5 & Upper Cache & $\mathbf{N}$ & 7920 & 240 & 82 & TFG \\
\hline 151 & & 1990 & & 44 & 99 & 10.1 & 110 & 05 & 57.4 & Upper Cache & & 7900 & 310 & 18 & TFG \\
\hline 153 & & 199 & & 44 & 48 & 15.0 & 110 & 06 & 02.2 & Upper Cache & $\mathrm{N}$ & & 0 & 0 & TFG \\
\hline 155 & & 1990 & & 44 & 48 & 13.9 & 110 & 13 & 15.4 & Above Opal Creek & & 9280 & 136 & 5 & FN \\
\hline 156 & & 1990 & & 44. & .48 & 28.6 & 110 & 13 & 59.2 & ror $\mathrm{Pl}$ & & & 208 & 28 & FNG \\
\hline 157 & & 1990 & & 44 & 48 & 53.1 & 110 & 14 & 11.3 & Mirror Platea & N & 9200 & 12 & 10 & FN \\
\hline 200 & & & 199 & 44 & 47 & 51.4 & 110 & 11 & 51.4 & Opal Creek & & & 200 & 12 & FNG \\
\hline 201 & & & 199 & 44 & 48 & 07.3 & 110 & 11 & 36.7 & Mirror Plateau & & 8920 & 260 & 3 & FNG \\
\hline 202 & & & 199 & 44 & 47 & 23.8 & 110 & 11 & 36.2 & Mirror Plateau & $\mathrm{N}$ & 8820 & 130 & 5 & FNG \\
\hline 203 & & & 1991 & 44 & 48 & 31.3 & 110 & 13 & 24.0 & Opal Creek & & 9080 & 200 & 8 & FNG \\
\hline 204 & & & 199 & 44 & 48 & 08.4 & 110 & 13 & 21.0 & Specimen Ridg & $\mathrm{N}$ & 9360 & 82 & 8 & FN \\
\hline 205 & & & 1991 & 44 & 49 & 08.7 & 110 & 14 & 09.1 & Opal Creek & No & 9160 & 210 & 5 & FNG \\
\hline 206 & & & 199 & 44 & 49 & 23.2 & 110 & 13 & 19.0 & Specimen Ridge Trail & $\mathbf{N}$ & 8680 & 160 & 18 & FNG \\
\hline 210 & & & 1991 & 44 & 51 & 43.1 & 110 & 10 & 09.7 & Lamar Flat & & & 0 & 0 & TE \\
\hline 211 & & & 1991 & 44 & 50 & 50.6 & 110 & 11 & 02.0 & Lamar Flat & $\mathbf{T}$ & 6720 & 0 & 0 & TF \\
\hline 212 & & & 199 & 44 & 51 & 25.7 & 110 & 10 & 33.7 & Lamar Flat & $\mathbf{T}$ & 6720 & 0 & 0 & TF \\
\hline 213 & & & 199 & 44 & 48 & 40.1 & 110 & 07 & 34.1 & Cache Calfee Ridge & $\mathrm{N}$ & 7720 & 0 & 0 & FNG \\
\hline 214 & & & 1991 & 44 & 49 & 08.5 & 110 & 07 & 49.7 & Cache Calfee Ridge & No & 7960 & 0 & 0 & FA \\
\hline
\end{tabular}

Burn rankings: No - unburned; T1 - severe burn; T2 - severe-moderate burn; T3 - moderate burn; T4 - light burn. See text for complete description.

${ }^{2}$ Despain (1990)

moderately burned sites. In contrast, forb biomass was higher in burned areas with a significant difference occurring in $1990(\underline{\mathrm{P}}<0.05)$.

\section{SPECTRAL INDICES AND VEGETATION CHARACTERISTICS}

The normalized difference index (NDVI) was the spectral index most highly correlated with 


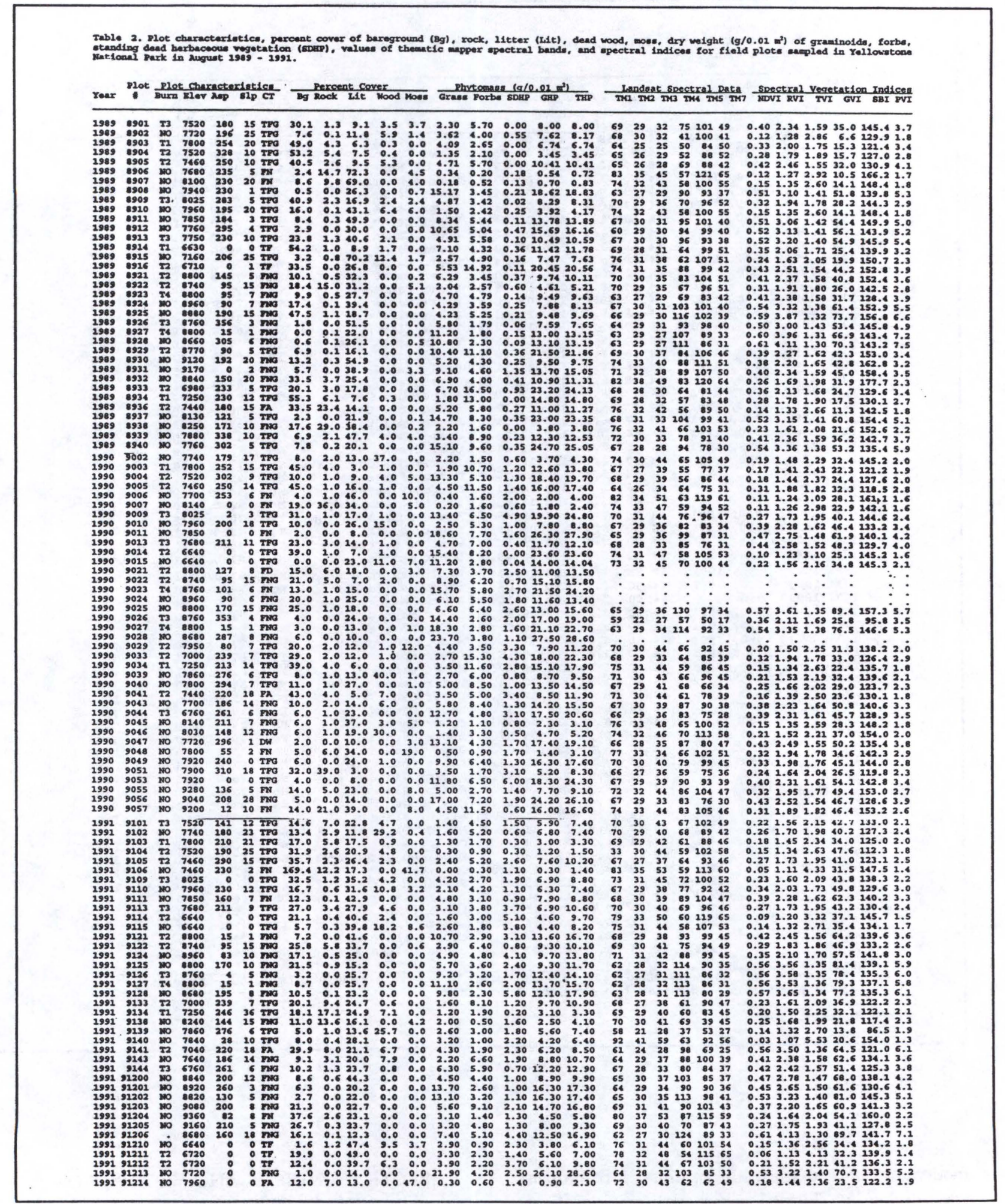

total and green vegetative characteristics (Table 3). There was considerable scatter, however, in the relationship between total (THP) and green herbaceous vegetation (GHP) when examined across 
years and no simple or multiple regression model could be found that explained more than $40 \%$ of the variation in NDVI in all years. In particular, data from 1990 had higher biomass for the same NDVI values as in other years. Because of differences in the timing of field sampling and satellite overpass in 1990, we did not use data collected in 1990 to develop our relationship between spectral NDVI and field estimates of phytomass. TVI and TM band 7 were most highly correlated with standing dead phytomass.

\begin{tabular}{|c|c|c|c|}
\hline \multicolumn{4}{|c|}{$\begin{array}{l}\text { Table 3. Significant }(\mathrm{P} \leq 0.05) \text { correlation coefficients between } \\
\text { TM spectral bands and spectral indices and vegetation } \\
\text { characteristics measured during late sumer 1989 - 1991 in. } \\
\text { Yellowstone National Park. NS indicates not significant. }\end{array}$} \\
\hline $\begin{array}{l}\text { Vegetative } \\
\text { Characteristic }\end{array}$ & Year & $\begin{array}{l}\text { Spectral } \\
\text { Index }\end{array}$ & $\underline{I}$ \\
\hline $\begin{array}{l}\text { Total standing } \\
\text { biomass }\end{array}$ & $\begin{array}{l}19 \overline{89} \\
1990 \\
1991\end{array}$ & $\begin{array}{l}\text { NUVI' } \\
\text { NDVI } \\
\text { NDVI }\end{array}$ & $\begin{array}{l}0.53 \\
0.45 \\
0.72\end{array}$ \\
\hline Green herbaceous phytomass & $\begin{array}{l}1989 \\
1990 \\
1991\end{array}$ & $\begin{array}{l}\text { NDVI } \\
\text { NUVI } \\
\text { NDVI }\end{array}$ & $\begin{array}{l}0.53 \\
0.46 \\
0.74\end{array}$ \\
\hline Green graminoids & $\begin{array}{l}1989 \\
1990 \\
1991\end{array}$ & $\begin{array}{l}\text { NDVI } \\
\text { NDVVI } \\
\text { NDVI }\end{array}$ & $\begin{array}{l}0.66 \\
0.48 \\
0.74\end{array}$ \\
\hline Green forbs & $\begin{array}{l}1989 \\
1990 \\
1991\end{array}$ & & $\begin{array}{l}\text { NS } \\
\text { NS } \\
\text { NS }\end{array}$ \\
\hline $\begin{array}{l}\text { Standing dead } \\
\text { herbaceous phytomass }\end{array}$ & $\begin{array}{l}1989 \\
1990 \\
1991\end{array}$ & & $\begin{array}{l}\text { NS } \\
\text { HS } \\
\text { NS }\end{array}$ \\
\hline $\begin{array}{l}\text { Percent standing dead } \\
\text { of total standing } \\
\text { phytomass }\end{array}$ & $\begin{array}{l}1989 \\
1990 \\
1991\end{array}$ & $\begin{array}{l}\mathrm{TVI}^{2}, \mathrm{TM}^{3} \\
\text { TM7 } \\
\text { TVI, THY7 }\end{array}$ & $\begin{array}{l}0.61,0.52 \\
0.35,0.42 \\
0.52,0.42\end{array}$ \\
\hline
\end{tabular}

THP and GHP alone explained 45 and $46 \%$ ( $\underline{P} 0.001)$ of the variation, respectively, in NDVI at field sites sampled in either 1989 or 1991. Elevation explained an additional $6 \%$ of the variation in NDVI (Table 4). Neither burn intensity nor standing dead herbaceous phytomass (SDHP) or the proportion of standing dead of THP explained additional variation in these data once the effects of elevation were accounted for. In contrast, the proportion of THP that was dead explained a significant amount of additional variation in NDVI if elevation were not included in the model. Burn intensity explained a significant amount of the variation in NDVI when combined with THP but not when combined with green grass GG or GHP (Table 4). Average percent canopy cover of other site characteristics that we measured, such as litter or bareground, did not contribute significantly to explaining additional variation in NDVI.

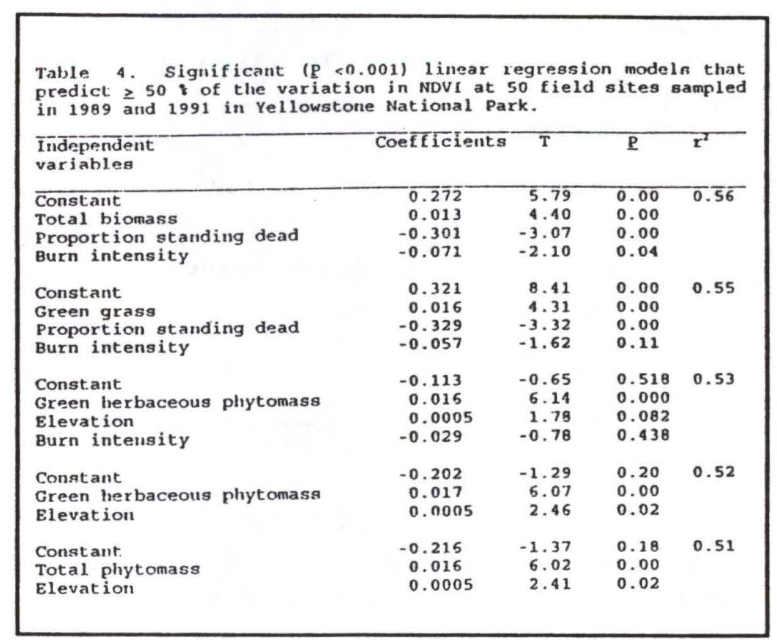

When the linear relationship was inverted to predict GHP, less than $50 \%$ of the variation in THP and GHP was explained by NDVI and elevation. The relationship appeared weak because many highelevation fields sites with high NDVI values had low GHP. As a result, we stratified sites by elevation and found that following linear models explained $55 \%$ of the variation in TGP and GHP at low elevational $(\leq 2620 \mathrm{~m})$ sites:

THP $\left(\mathrm{g} / 0.1 \mathrm{~m}^{2}\right)=29.25 \times$ NDVI-1.191 $\quad$ P $<0.001$, s.e. $=$ 4.61)

Eq. 1 4.54)

Eq. 2

Using an exponential model, NDVI explained only an additional $1 \%$ of the variation in either THP or GHP.

The relationship between NDVI and phytomass at high elevation was nonlinear and the following curves were used to describe the relationships:

$$
\begin{aligned}
& \operatorname{THP}\left(\mathrm{g} / 0.1 \mathrm{~m}^{2}\right)=\frac{19 \times(\mathrm{NDVI}-0.18)}{0.110+(\mathrm{NDVI}-0.18)} \\
& \operatorname{GHP}\left(\mathrm{g} / 0.1 \mathrm{~m}^{2}\right)=\frac{17 \times(\mathrm{NDVI}-0.18)}{0.102+(\mathrm{NDVI}-0.18)}
\end{aligned}
$$

Eq. 3

Eq. 4

The above equations were used to predict the 
THP and GHP of 16 low elevation sites and 7 high elevation sites that were not used to develop the above predictive equations. On average, GHP was underestimated at low elevations by $0.93 \mathrm{~g} / \mathrm{m}^{2}$ and THP overestimated by $1.01 \mathrm{~g} / 0.01 \mathrm{~m}^{2}$. At high elevations, GHP was overestimated by $2.34 \mathrm{~g} / 0.01$ $\mathrm{m}^{2}$ and THP by $2.73 \mathrm{~g} / 0.01 \mathrm{~m}^{2}$. Mean percent error in estimates of GHP (37\%) at low elevations was greater than at high elevations (24\%) because phytomass was generally lower at low elevation sites than at high elevations sites.

\section{$\checkmark \quad$ FUTURE ANALYSES}

We intend to use the biomass-spectral relationships to characterize herbaceous vegetative recovery in the sagebrush-grassland areas in our study area. Our approach is to import TM spectral bands 3 and 4 from Landsat imagery for 1989, 1990, 1991 for our study area and to geo-reference the coverages to Yellowstone National Park's burned area and elevation coverages in ARC/INFO GRID. Next, we will stratify the area by elevation and identify nonforested areas of the study using the YNP habitat type map. Within each elevational stratum, we will use the NDVI-biomass algorithm developed for that elevation to predict the green and total biomass on a pixel-by-pixel basis and calculated the average for both burned and unburned areas. Initial attempts to complete this analysis were thwarted by what we believed to be either major geo-referencing problems or discrepancies between the burned areas and habitat types and what was evident on the Landsat imagery. Once these corrections have been made we can complete our analyses.

\section{ACKNOWLEDGEMENTS}

I would like to thank Cathy Wilson for her assistance in field work and initial data analysis. John Baldwin, Jon Hak, Robin Reid, Verda and Mike Shingleton, Greg McDaniel, and Bob Brennen provided help in collecting field data and processing samples. We also thank Rich Kluckus, Don Despain, Francis Singer, John Varley, Jennifer Whipple, George McKay, and Jack Norland of Yellowstone National Park for their administrative and field support. Drs. Kenneth Gerow and Jeff Pontius of the University of Wyoming provided statistical advice.

\section{$\checkmark \quad$ Literature Cited}

Despain, D. G. 1990. Yellowstone Vegetation: consequences of environment and history in a natural setting. Roberts Rinehart. 239 pp.

Eberhardt, L. L. and M. A. Simmons. 1987. Calibrating population indices by double sampling. J. Wildl. Manage. 51:665-675.

Hall, D. K. J. P. Ormsby, L. Johnson, and J. Brown. 1980. Landsat digital analysis at Kokolik River, Alaska. Remote Sens. Environ. 10:263-272.

Hardinsky, M.A., F. C. Daiber, C.T. Roman, and V. Klemas. 1984. Remote sensing of biomass and annual net aerial primary productivity of a salt marsh. Remote Sens. of Environ. 16:91-106.

Houston, D. B. 1982. The Northern Yellowstone elk: ecology and management. Macmillian Publishing, New York. 474 pp.

Huete, A. R. and R.D. Jackson. 1987. Suitability of spectral indices for evaluating vegetation characteristics on arid rangelands. Remote Sens. of Environ. 23:213-232.

Huete, A. R., R. D. Jackson, D.F. Post. 1985. Spectral response of a plant canopy with different soil backgrounds. Remote Sens. of Environ. 17:37-53.

Jackson, R. D. 1983. Spectral indices in n-Space. Remote Sens. of Environ 13: 409-421.

Jakubauskas, M., K. P. Lulla and P. W. Mausel. 1990. Assessment of vegetation change in a fire-altered forest landscape. Photogr. Eng. Remote Sens. 56:371-377.

Merrill, E. H., M. K., Bramble-Brodahl, R. W. Marrs, M. S. Boyce. 1993. Estimation of green herbaceous phytomass from Landsat MSS data in Yellowstone National Park. J. Range Manage. 46:151-157. 
Pearson, R.L., C. J. Tucker, and L.D. Miller. 1976. Spectral mapping of short grass prairie biomass. Photogramm. Eng. Remote Sens. 42:317-3245.

Shibayama, M. and T. Akiyama. 1989. Seasonal visible, near-infrared and mid-infrared spectra of rice canopies in relation to LAI and above-ground dry phytomass. Remote Sens. of Environ. 27:119-127.
Sellers, P.J. 1985. Canopy reflectance, photosynthesis and transpiration. Int. J. Remote Sens. 6:1335-1372.

Tueller, P. T. 1989. Remote sensing technology for rangeland management applications. J. Range Manage. 42: 442-453. Remote Sens. of Environ. 8:127-150. 
138

Appendix I. Equations used to calibrate spectral values from Landsat imagery for Yellowstone National Park on 13 August 1990 and 31 July 1991 to August 2, 1989 for 6 thematic mapper (TM) spectral bands.

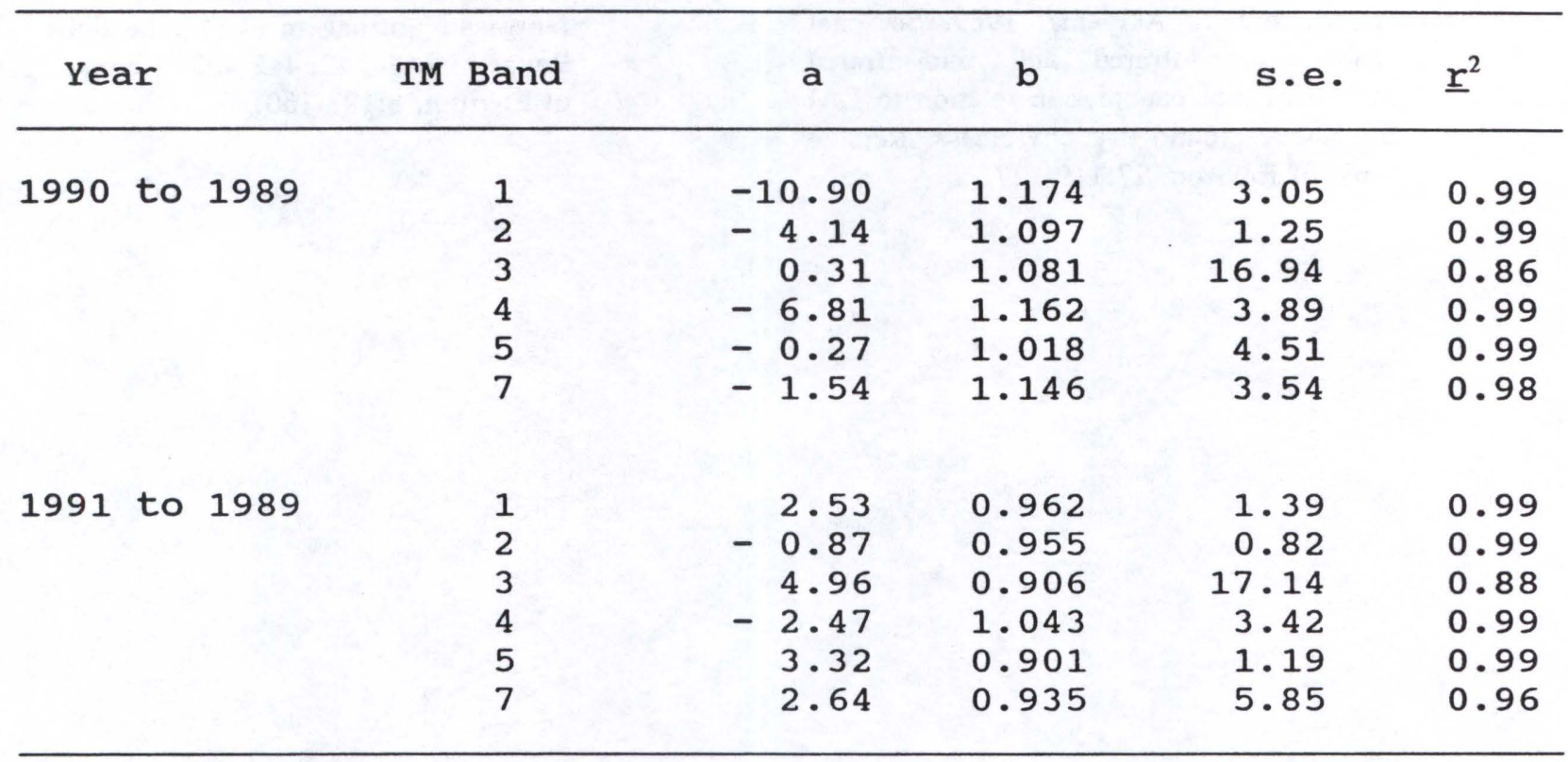

